\title{
Preman dalam Jejak Sejarah Indonesia
}

\author{
Nurul Azizah \\ Email: $1810111120002 @$ mhs.ulm.ac.id \\ Program Studi Pendidikan Sejarah Fakultas Keguruan dan Ilmu Pendidikan \\ Universitas Lambung Mangkurat \\ Banjarmasin
}

\begin{abstract}
Abstrak
Sejarah merupakan sesuatu yang tidak bisa ditinggalkan. Sejarah memuat rangkaianrangkaian aktifitas manusia yang akan terus bergerak mengikuti sifat manusia yang dinamis. Peristiwa-peristiwa yang mempunyai dampak besar bagi kehidupan akan dicatat dan didokumentasikan sebagai ilmu yang akan dipelajari diwaktu yang akan datang. Indonesia, negara yang sudah merdeka selama 75 tahun ini juga banyak menyimpan peristiwa sejarah dalam setiap perjalanan waktunya. Peristiwa-peristiwa sejarah Indonesia akan diurutkan mulai dari jaman prasejarah hingga masa kerajaan dan kemudian masa meraih kemerdekaan. Urutan-urutan peristiwa tersebut banyak yang menjadi penguat identitas bangsa. Aktifitas manusia yang bersifat dinamis mampu menggeser makna dari peristiwa sejarah, bahkan bisa merubah makna dari suatu kelompok. Salah satunya terjadi pada perubahan konotasi pada preman. Preman pada jaman kolonial dianggap sebagai pembela buruh yang tertindas oleh tuan-tuan tanah Belanda. Kini preman dianggap sebagai kelompok yang meresahkan masyarakat, bahkan tak jarang diberi julukan sebagai "Sampah masyarakat"

Kata kunci : Preman, Sejarah, Masyarakat.

\section{PENDAHULUAN}

Selama 75 tahun Indonesia merdeka, banyak sekali peristiwa bersejarah yang telah dilalui Indonesia. Peristiwa-peristiwa yang cukup besar, akan dicatat dan diarsipkan oleh negara, namun tak jarang peristiwa-peristiwa kecil juga termasuk ke dalam catatan arsip negara Indonesia sebagai potongan sebuah peristiwa besar. Bahkan, ada beberapa peristiwa bersejarah di Indonesia yang menjadi penguat identitas bangsa Indonesia. Sebagai rakyat Indonesia, tentu kita
\end{abstract}


harus mengetahui peristiwa sejarah yang ada di Indonesia. "Jangan lupakan sejarah(Jasmerah)" begitulah ucap bapak proklamator Indonesia, Ir.Soekarno.Membahas tentang sejarah, sejarah merupakan salah satu cabang dari ilmu pengetahuan. Jadi bukan hanya berisi mengenai mitos, legenda dan tahayul, sejarah juga berisi Ilmu yang bisa dipelajari dan dibagikan kepada khalayak banyak. Oleh sebab itulah, peristiwa sejarah dicatat didalam arsip untuk mendokumentasi ilmu yang akan dipakai dikemudian hari.

Sejarah memiliki rentang waktu karena aktivitas manusia yang terjadi secara terusmenerus, maknanya sejarah bersifat dinamis dan akan mengalami perubahan terus menerus. Sejarah hanya akan berhenti jika waktu diberhentikan oleh Yang Maha Esa. (Anis, 2015:54). Karena sifatnya yang dinamis, biasanya beberapa peristiwa sejarah mengalami pergeseran makna dan tujuan. Selain itu, sifat dinamis dari sejarah ini juga membuat beberapa kata mengalami pergeseran makna.

Peyorasi mempunyai arti proses pergeseran makna dari sebelumnya yang bersifat positif menjadi terdengar lebih negatif, buruk, atau rendah. Peyorasi ini bisa ditelusuri melalui peristiwa sejarah. Salah satu kata yang mengalami peyorasi ini adalah preman. Preman dalam KBBI merupakan sebuah sebutan untuk orang yang melakukan kejahatan seperti pemerasan dan penodongan. Stereotip preman dalam masyarakat adalah orang yang memiliki lukisan pada tubuh dan memiliki kaitan erat dengan kekerasan dan kesewenangan. Preman digambarkan sebagai orang jahat yang keluar masuk penjara dan sering memeras orang-orang tak berdaya di sekitarnya.

\section{PREMAN PADA MASA KOLONIALISME}

Jika dilihat dari catatan sejarah Indonesia, preman merupakan sosok pembela bagi rakyat kecil dan buruh yang ditindas. Tepatnya pada masa kolonial belanda, pereman atau Vrijman ini dipandang masyarakat sebagai pembela para buruh kebun dan pabrik milik Belanda yang disiksa oleh mandor mereka. Nama preman ini diberikan oleh tuan-tuan kebun Belanda atau Planters, Vrijman yang berarti orang bebas, artinya mereka tak terikat dalam kontrak kerja apapun. Sejatinya preman ini merupakan pekerja lepas atau buruh harian yang juga dipekerjakan Belanda, namun juga sebagai peneror Belanda jika melakukan penindasan 
terhadap buruh lain. Cara preman membela buruh ini cukup beragam, merusak tanaman kebun, minum-minum sampai mabuk dan memancing keributan, hingga menantang berkelahi para planters. Dalam tulisan Kompas pada 30 November 1986 yang dikutip oleh Voi pada 20 Januari 2020. Para preman digeratiskan untuk mengambil makanan dan minuman di warung milik masyarakat atas jasa pembelaan yang dilakukan oleh mereka. Dari fenomena inilah istilah vrij man berubah menjadi preman yang merupakam akronim dari "pre minum pre makan", pre disingkat dari prei, yang berasal dari kata $v r i j$.

Sejak saat itu, preman digambarkan sebagai image pembela kaum buruh yang ditindas dengan cara menebar keresahan dan bisa diupah dengan memberikan makanan dan minuman gratis, singkatnya cara kerja preman yang menebar keresahan dan diupah dengan makan minum secara gratis di warung, sekarang lebih dikenal dengan uang keamanan. Pada masa menuju kemerdekaan, para preman juga turut andil dalam memperjuangkan kemerdekaan dengan bergabung ke dalam laskar-laskar pejuang. Dikutip dari laman artikel Historia, Pada peristiwa Jalan Bali, Medan, pada Oktober 1945 adalah salah satu bukti medan juang preman melawan penjajah. Kabarnya pun, Jenderal Nasution pernah menggunakan jasa preman untuk menekan Presiden Sukarno membubarkan parlemen. (Ian, 2010: 201).

\section{MASA SETELAH KEMERDEKAAN}

Beberapa tahun pasca kemerdekaan, preman masih memiliki pandangan positif di mata masyarakat. Bahkan, dikutip dalam laman artikel Historia, Wali kota Medan yang menjabat pada tahun 1954-1958, Haji Moeda Siregar pernah memberikan penghargaan kepada preman atas aksi

mereka meredamkan kekacauan yang ada di Medan. Selain itu preman juga menjadi tempat pengaduan masyarakat yang mengalami pencurian dan perampokan, dengan maksud preman tersebut akan menghubungi komplotan pencuri sekitar tempat untuk mengembalikan barang curian tersebut.

Pada masa pemerintahan Soekarno, preman dihimpun dalam satu organisasi yang bernama Pemuda Pancasila (PP). Pemuda Pancasila didirikan sebagai organisasi sayap Partai Ikatan Pendukung Kemerdekaan Indonesia (IPKI) yang dibentuk Jenderal Abdul Haris Nasution pada 28 Oktober 1959. Pemuda Pancasila secara formal diresmikan dalam kongres IPKI tahun 
1961. Perlahan muncul oknum-oknum preman yang hanya berorientasi pada kekuatan dan uang, merusak pandangan positif pada preman yang sudah ada sebelumnya. Oknum ini dimanfaatkan oleh para tuan tanah untuk dijadikan sebagai tukang pukul mereka..Seiring berjalannya waktu, jumlah oknum-oknum ini mulai meningkat dan banyak sekali kasus penyalahgunaan kekuasaan yang dilakukan oleh preman. Pada akhirnya sosok vrije man sebagai pembela buruh dan masyarakat digantikan sebagai preman, para pengganggu masyarakat yang meresahkan.

Pada masa pemerintahan Soeharto, nama preman mulai naik kembali setelah adanya operasi pemberantasan kejahatan "Operasi Celurit” yang dicetuskan oleh Kodam Jaya pada awal Januari 1983. Dalam operasi itu, Kodam Jaya berada langsung di bawah komando Pangkopkamtib Sudomo. Menurut keterangan Soedomo pada Sinar Harapan, 27 Juli 1983 operasi itu tidak hanya ditujukan untuk menindak pelaku kejahatan, melainkan juga untuk menginventarisasi nama-nama pelakunya. Preman yang dianggap meresahkan masyarakat pun menjadi salah satu target operasi ini. Banyak sekali mayat-mayat misterius yang bergelimpangan di jalanan. Mayat-mayat tersebut dibiarkan sebagai upaya shock therapy bagi preman yang berniat untuk mengganggu masyarakat setempat. Operasi pemberantasan tersebut hanya eksis pada masa pemerintahan Soeharto saja, setelah masa pemerintahan Soeharto usai, berakhir pula operasi pemberantasan kejahatan ini,

Begitulah jejak preman dalam sejarah Indonesia, walaupun sekarang preman dianggap kelompok yang meresahkan masyarakat, kita tidak bisa menolak bahwa preman juga ikut andil dalam mempertahankan kemerdekaan Indonesia.

\section{SIMPULAN}

Preman berasal dari panggilan tuan-tuan tanah Belanda yang bekerja lepas atau buruh harian di kebun Belanda. Pada masa kolonial belanda, pereman atau Vrijman ini dipandang masyarakat sebagai pembela para buruh kebun dan pabrik milik Belanda yang disiksa oleh mandor mereka. Preman ini membela para buruh dengan cara meneror pemilik tanah, aksi peneroran biasanya dilakukan dengan merusak tanaman kebun, minum-minum sampai mabuk dan memancing keributan, hingga menantang berkelahi para planters.Buruh-buruh ini berterima 
kasih dengan preman dengan cara memberikan mereka makanan gratis di warung yang mereka miliki.

Preman juga turut andil dalam perjuangan kemerdekaan Indonesia, mereka tergabung dalam lascar-laskar perjuangan. Nama preman sungguh dipandang masyarakat dengan konotasi positif dan kehadirannya tidak membuat masyarakat merasa was-was. Pandangan masyarakat kepada preman mulai berubah menjadi negatif saat anyaknya oknum preman yang menyalahgunakan kekuasaan hingga meresahkan masyarakat. Preman pun sempat dibasmi pada masa pemerintahan Soeharto karena menjadi salah satu target operasi pemberantasan kejahatan.

\section{REFRENSI}

\section{Jurnal :}

Anis, M. Z. A. (2015). Sejarah Bukan Warisan Melainkan Pembelajaran.

Wilson, Ian. (2010). The Rise and Fall of Political Gangster.

\section{Web :}

Triyana, B.(2010). Petrus: Kisah Gelap Orba. Diakses dari https://historia.id/politik/articles/petrus-kisah-gelap-orba-PyXNv/page/1

Menelusuri Asal Kata 'Preman' yang Jauh dari Konotasi Negatif. (2020). Diakses dari https://voi.id/memori/1867/menelusuri-asal-kata-preman-yang-jauh-dari-konotasi-negatif

Martin, S, Preman Medan dari Zaman ke Zaman. (2016). Diakses dari https://historia.id/urban/articles/preman-medan-dari-zaman-ke-zaman-P1Bm4/page/2 